\title{
BID wt Allele
}

National Cancer Institute

\section{Source}

National Cancer Institute. BID wt Allele. NCI Thesaurus. Code C49372.

Human BID wild-type allele is located in the vicinity of 22 q11.21 and is approximately 40 $\mathrm{kb}$ in length. This allele, which encodes $\mathrm{BH}$-interacting domain death agonist protein, plays a role in the regulation of apoptosis and is a mediator of mitochondrial damage resulting from caspase activation. 